\title{
High-temperature thermal functions and the thermochemistry of zinc tungstate *
}

\author{
WILLIAM G. LYON $^{b}$ and EDGAR F. WESTRUM, JR ${ }^{c}$ \\ Department of Chemistry, The University of Michigan, \\ Ann Arbor, Michigan 48104, U.S.A.
}

(Received 27 November 1973)

\begin{abstract}
Combination of low-temperature heat capacities with results from drop calorimetry has yielded a provisional set of thermal functions for $\mathrm{ZnWO}_{4}(\mathrm{c})$ up to $1200 \mathrm{~K}$. These hightemperature thermal functions permit an analysis of the thermochemistry of zinc tungstate and the selection of the value $-(294.6 \pm 0.3) \mathrm{kcal}_{\mathrm{th}} \mathrm{mol}^{-1}$ for the standard enthalpy of formation at $298.15 \mathrm{~K}$.
\end{abstract}

\section{Introduction}

The thermochemistry of many transition metal tungstates has been reviewed by Urosov et al. $;^{(1)}$ however, in most instances the paucity of data concerning the thermal functions of these materials has severely hindered accurate analysis or comparison of enthalpies of formation at $298.15 \mathrm{~K}$. This problem is particularly serious for situations involving analysis of high-temperature equilibrium data, since these cases require accurate values for the entropy. The recently determined values for the thermal functions of $\mathrm{ZnWO}_{4}{ }^{(2,3)}$ from 5 to $550 \mathrm{~K}$ permit an accurate analysis of the thermochemistry of this compound.

\section{Thermal functions}

From drop-calorimetric measurements of Zharkova and Rezukhina, ${ }^{(4)}$ and heatcapacity measurements, ${ }^{(3)}$ it was possible to generate a provisional set of hightemperature thermal functions for $\mathrm{ZnWO}_{4}$. These functions, presented in table 1, are based on $298.15 \mathrm{~K}$ as the standard temperature; thus, they are a more convenient set of functions for use in equilibrium calculations involving $\mathrm{ZnWO}_{4}$ as one reactant.

The only published thermal functions of comparable range for a tungstate of the $\mathrm{NiWO}_{4}$-type are those given by $\mathrm{JANAF}^{(5)}\left(31 \mathrm{March}\right.$ 1967) for $\mathrm{MgWO}_{4}$. These

- This work was supported in part by the Division of Research of the U.S. Atomic Energy Commission (AEC Cryogenics Project AT(11-1)-1149), and in recent months by the National Science Foundation (Project NSF GP-3342X).

- Abstracted in part from a dissertation submitted in partial fulfilment of the requirements for the Ph.D. degree from the Horace H. Rackham School of Graduate Studies at The University of Michigan.

- To whom correspondence concerning this paper should be directed. 
TABLE 1. High-temperature thermal functions of zinc tungstate $\left(\mathrm{cal}_{\mathrm{th}}=4.184 \mathrm{~J}\right)$

\begin{tabular}{rcccc}
\hline$\frac{T}{\mathrm{~K}}$ & $\frac{C_{p}}{\mathrm{cal}_{\mathrm{th}} \mathrm{K}^{-1} \mathrm{~mol}^{-1}}$ & $\frac{\left\{S^{\circ}(T)-S^{\circ}(0)\right\}}{\mathrm{cal}_{\mathrm{th}} \mathrm{K}^{-1} \mathrm{~mol}^{-1}}$ & $\frac{\left\{H^{\circ}(T)-H^{\circ}(298.15 \mathrm{~K})\right\}}{\mathrm{cal}_{\text {th }} \mathrm{mol}^{-1}}$ & $\frac{-\left\{G^{\circ}(T)-H^{\circ}(298.15 \mathrm{~K})\right\} / T}{\mathrm{cal}_{\mathrm{th}} \mathrm{K}^{-1} \mathrm{~mol}^{-1}}$ \\
\hline 300 & 27.38 & 28.51 & 50.586 & 28.34 \\
400 & 30.83 & 36.90 & 2976.3 & 29.46 \\
500 & 32.85 & 44.02 & 6169.4 & 31.68 \\
600 & 34.06 & 50.12 & 9519.8 & 34.26 \\
700 & 34.85 & 55.44 & 12968 & 36.91 \\
800 & 35.45 & 60.13 & 16484 & 39.53 \\
900 & 35.97 & 64.34 & 20055 & 42.05 \\
1000 & 36.44 & 68.15 & 23677 & 44.48 \\
1100 & 36.86 & 71.65 & 27342 & 46.79 \\
1200 & 37.26 & 74.87 & 31048 & 49.00 \\
\hline
\end{tabular}

latter functions, however, were extrapolated without benefit of drop-calorimetric data above $300 \mathrm{~K}$, and neglected entirely the transition between 1373 and $1573 \mathrm{~K}$ reported by Dunning and Megaw. ${ }^{(6)}$

Due partly to the small number of results from drop calorimetry (only four points) and partly to the relatively high curvature of the $\mathrm{ZnWO}_{4}$ heat capacity, even in the high-temperature region, it was found impossible to joint the low-temperature and high-temperature data smoothly by simple graphical means of the type suggested by Shomate. ${ }^{(7)}$ An attempt at such a plot of the quantity:

$$
\left\{H^{\circ}(T)-H^{\circ}(298.15 \mathrm{~K})-C_{p}(298.15 \mathrm{~K})(T-298.15 \mathrm{~K})\right\} T /(T-298.15 \mathrm{~K})^{2} \text {, }
$$

against $T$ (which should yield a straight line), seemcd to indicatc either that the implicit representation of $C_{p}$ in the form $a+2 b T-c / T^{2}$ was inadequate in this temperature region, or that the drop-calorimetric results and the lower-temperature results are badly discordant. It was assumed for the purposes of this analysis that the former explanation of the non-linearity is correct.

To avoid the diffculties described above, the heat capacity was extrapolated directly, using adjacent drop-calorimetric enthalpy determinations to obtain average heat capacity values in the high-temperature region. Comparison of $\left\{H^{\circ}(T)-H^{\circ}\left(T^{*}\right)\right\}$ obtained from this extrapolation with values measured by Zharkova and Rezukhina ${ }^{(4)}$ is given in table 2 . Although the agreement obtained is reasonable, further measurements-through melting if possible-would be desirable.

At the highest temperature given in table $1(1200 \mathrm{~K})$, the heat capacity exceeds the harmonic limit $(18 R)$ by approximately 4 per cent; this is considered a reasonable deviation for heat capacities at nearly $0.8 T_{\mathrm{m}} \cdot\left(T_{\mathrm{m}}\right.$ for $\mathrm{ZnWO}_{4}$ has been reported $\left.{ }^{(8,9)}\right)$ A similar deviation from the harmonic limit is found for $\mathrm{WO}_{3}(\mathrm{c})$ at $0.8 T_{\mathrm{m}}$. (Compare JANAF, ${ }^{(5)} 30$ September 1966.) The presence of a small transition below melting such as that observed by Yakovleva and Rezukhina ${ }^{(10)}$ for $\mathrm{CoWO}_{4}\left(\Delta H_{\mathrm{t}}=445 \mathrm{cal}_{\mathrm{th}}\right.$ $\mathrm{mol}^{-1}$ at about $986 \mathrm{~K}$ ) is not necessarily excluded by the apparent agreement obtained in this work. $\dagger$

$\dagger$ Throughout this paper $\mathrm{cal}_{\mathrm{th}}=4.184 \mathrm{~J}$. 
TABLE 2. Comparison of enthalpy increments for zinc tungstate $\left(\mathrm{cal}_{\mathrm{th}}=4.184 \mathrm{~J}\right)$

\begin{tabular}{|c|c|c|c|c|}
\hline$\frac{T}{\mathrm{~K}}$ & ${\frac{H^{\circ}(T)-H^{\circ}(293.2 \mathrm{~K})}{\mathrm{cal}_{\mathrm{th}} \mathrm{mol}^{-1}}}^{\alpha}$ & ${\frac{H^{\circ}(T)-H^{\circ}(298.15 \mathrm{~K})}{\mathrm{cal}_{\mathrm{th}} \mathrm{mol}^{-1}}}^{\mathrm{b}}$ & ${\frac{H^{\circ}(T)-H^{\circ}(298.15 \mathrm{~K})}{\mathrm{cal}_{\mathrm{th}} \mathrm{mol}^{-1}}}^{c}$ & $\frac{\Delta(\Delta H)}{\mathrm{cal}_{\mathrm{tb}} \mathrm{mol}^{-1}}$ \\
\hline 750.5 & 14724 & 14860 & 14735 & 125 \\
\hline 905.4 & 20190 & 20326 & 20247 & 79 \\
\hline 1009.3 & 23955 & 24091 & 24012 & 79 \\
\hline 1095.6 & 27118 & 27254 & 27178 & 76 \\
\hline
\end{tabular}

a Data of Zharkova and Rezukhina ${ }^{(4)}$ converted to molar basis.

${ }^{b}$ Data of Zharkova and Rezukhina ${ }^{(4)}$ molar data adjusted to $298.15 \mathrm{~K}$ as base temperature, using the cryogenic $C_{p}$ results obtained by Lyon and Westrum. ${ }^{(3)}$

- Enthalpy function computed from extrapolated $C_{\mathrm{p}}$ as described in text.

${ }^{d}$ Difference: $\left\{H^{\circ}(T)-H^{\circ}(298.15 \mathrm{~K})\right\}_{\text {expt }}-\left\{H^{\circ}(T)-H^{\circ}(298.15 \mathrm{~K})\right\}_{\text {ealc. }}$.

\section{Thermochemistry}

The availability of thermal functions for $\mathrm{ZnWO}_{4}$ enables tests for concordance in the previously published thermochemical data. Accordingly, the equilibrium data of Zharkova et al., ${ }^{(1)}$ and the more recent solution calorimetric data of Navrotsky and Kleppa ${ }^{(12)}$ were reduced by standard methods of analysis for comparison at $298.15 \mathrm{~K}$.

\section{EQUILIBRIUM DATA}

The equilibrium data of Zharkova et al. ${ }^{(11)}$ for the reaction:

$$
\mathrm{ZnWO}_{4}(\mathrm{c})+4 \mathrm{H}_{2}(\mathrm{~g})=\mathrm{Zn}(\mathrm{g})+\mathrm{W}(\mathrm{c})+4 \mathrm{H}_{2} \mathrm{O}(\mathrm{g}) \text {, }
$$

were subjected to both second- and third-law analyses. For the second-law analysis, $\ln K_{p}$ for the reaction was curve-fitted by least squares to the form:

$$
\text { ln } K_{p}=A+B / T+C \ln T \text {. }
$$

From the slope calculated at the midpoint of the range of measurements, the enthalpy of reaction was computed, which was subsequently reduced to $298.15 \mathrm{~K}$ and combined with other thermochemical data to yield the standard enthalpy of formation $\Delta H_{\mathrm{f}}^{\circ}$ of $\mathrm{ZnWO}_{4}$. The details of this calculation, and the subsidiary data used, are given in table 3.

The third-law analysis of these equilibrium data was carried out using $-\left\{G^{\circ}(T)-H^{\circ}(298.15 \mathrm{~K})\right\} / T$ for the various reactants, curve-fitted to the form:

$$
-\left\{G^{\circ}(T)-H^{\circ}(298.15 \mathrm{~K})\right\} / T=A+B / T+C / T^{2}+D \ln T .
$$

The results of this analysis are shown in table 4.

\section{SOLUTION-CALORIMETRIC DATA}

The direct calorimetric data of Navrotsky and Kleppa ${ }^{(12)}$ required little more than reduction to $298.15 \mathrm{~K}$ via the relevant enthalpy increments. A description of the thermochemical system involved and these results are presented in table 5. 
TABLE 3. Second-law analysis of the data of Zharkova et al. ${ }^{(11)}$ $\left(\mathrm{cal}_{\mathrm{th}}=4.184 \mathrm{~J}\right)$

\begin{tabular}{|c|c|c|}
\hline \multicolumn{2}{|l|}{ Reaction } & $\frac{\Delta H_{\mathrm{r}}^{\circ}}{\mathrm{kcal}_{\mathrm{th}} \mathrm{mol}^{-1}}$ \\
\hline \multicolumn{3}{|c|}{$\mathrm{ZnWO}_{4}(\mathrm{c}, 1116 \mathrm{~K})+4 \mathrm{H}_{2}(\mathrm{~g}, 1116 \mathrm{~K})=\mathrm{Zn}(\mathrm{g}, 1116 \mathrm{~K})+\mathrm{W}(\mathrm{c}, 1116 \mathrm{~K})$} \\
\hline \multicolumn{2}{|l|}{$\mathrm{ZnWO}_{4}(\mathrm{c}, 298.15 \mathrm{~K})=\mathrm{ZnWO}_{4}(\mathrm{c}, 1116 \mathrm{~K})$} & $(27.93 \pm 0.08)^{\circ}$ \\
\hline \multicolumn{2}{|l|}{$4 \mathrm{H}_{2}(\mathrm{~g}, 298.15 \mathrm{~K})=4 \mathrm{H}_{2}(\mathrm{~g}, 1116 \mathrm{~K})$} & $23.154^{c}$ \\
\hline \multicolumn{2}{|l|}{$\mathrm{Zn}(\mathrm{g}, 1116 \mathrm{~K})=\mathrm{Zn}(\mathrm{g}, 298.15 \mathrm{~K})$} & $-4.063^{a}$ \\
\hline \multicolumn{2}{|l|}{$W(c, 1116 K)=W(c, 298.15 K)$} & $-5.135^{e}$ \\
\hline \multicolumn{2}{|l|}{$4 \mathrm{H}_{2} \mathrm{O}(\mathrm{g}, 1116 \mathrm{~K})=4 \mathrm{H}_{2} \mathrm{O}(\mathrm{g}, 298.15 \mathrm{~K})$} & $-29.505^{f}$ \\
\hline \multicolumn{2}{|l|}{$\mathrm{Zn}(\mathrm{g}, 298.15 \mathrm{~K})=\mathrm{Zn}(\mathrm{c}, 298.15 \mathrm{~K})$} & $-(31.170 \pm 0.10)^{s}$ \\
\hline \multicolumn{2}{|l|}{$4 \mathrm{H}_{2} \mathrm{O}(\mathrm{g}, 298.15 \mathrm{~K})=4 \mathrm{H}_{2} \mathrm{O}(1,298.15 \mathrm{~K})$} & $-42.076^{h}$ \\
\hline \multicolumn{2}{|c|}{$4 \mathrm{H}_{2} \mathrm{O}(\mathrm{l}, 298.15 \mathrm{~K})=4 \mathrm{H}_{2}(\mathrm{~g}, 298.15 \mathrm{~K})+2 \mathrm{O}_{2}(\mathrm{~g}, 298.15 \mathrm{~K})$} & $273.260^{i}$ \\
\hline \multicolumn{2}{|c|}{$\mathrm{ZnWO}_{4}(\mathrm{c}, 298.15 \mathrm{~K})=\mathrm{Zn}(\mathrm{c}, 298.15 \mathrm{~K})+\mathrm{W}(\mathrm{c}, 298.15 \mathrm{~K})+2 \mathrm{O}_{2}(\mathrm{~g}, 298.15 \mathrm{~K})$} & $(294.3 \pm 0.6)$ \\
\hline $\begin{array}{l}\text { a Zharkova et al. } .^{(11)} 8 \text { points. } \\
\text { o Zharkova and Rezukhina }{ }^{(4)} \text { (see table 1). } \\
\text { c JANAF }{ }^{(5)} \text { (31 March 1961). } \\
\text { d Hultgren et al } l^{(13)} \\
\text { - JANAF }{ }^{(5)} \text { (30 June 1966). }\end{array}$ & $\begin{array}{l}f \text { JANAF }^{(5)}(31 \text { March } \\
\text { g Hultgren et al. } .^{(13)} \\
{ }^{n} \text { Wagman et al. } .^{(14)} \\
{ }^{t} \text { Wagman et al. } .^{(15)}\end{array}$ & 1961). \\
\hline
\end{tabular}

TABLE 4. Third-law analysis of the data of Zharkova et al. ${ }^{(11)}$ for the reaction:

$$
\begin{gathered}
\mathrm{ZnWO}_{4}(\mathrm{c})+4 \mathrm{H}_{2}(\mathrm{~g})=\mathrm{Zn}(\mathrm{g})+\mathrm{W}(\mathrm{c})+4 \mathrm{H}_{2} \mathrm{O}(\mathrm{g}) \\
\left(\mathrm{cal}_{\mathrm{th}}=4.184 \mathrm{~J}\right)
\end{gathered}
$$

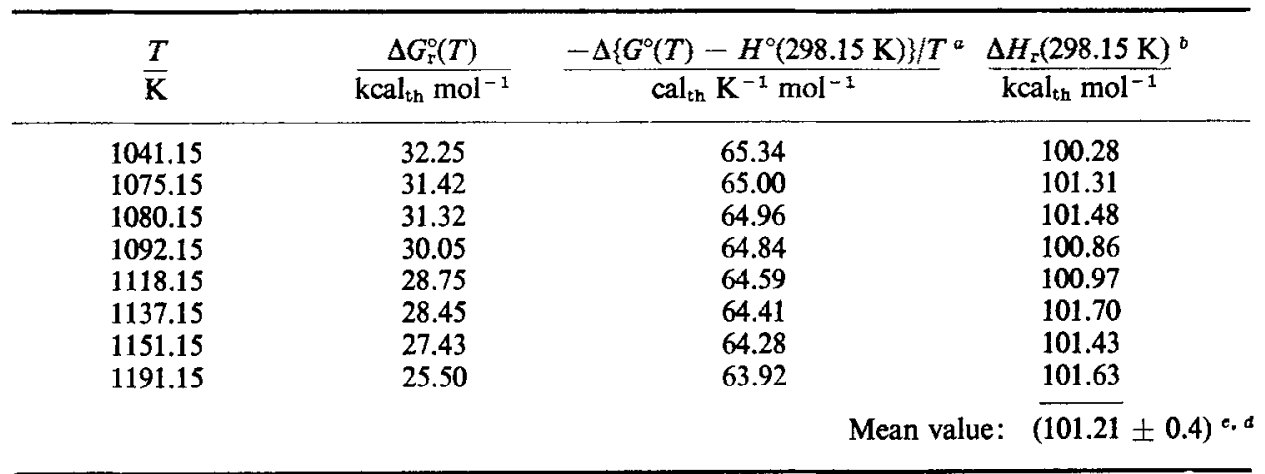

a The values for the reactants were based on data from the following sources: $\mathrm{ZnWO}_{4}(\mathrm{c})$, table 1; $\mathrm{H}_{2}(\mathrm{~g})$, JANAF(B) (31 March 1961); Zn(g), Hultgren et al.; ${ }^{(13)}$ W(c), JANAF ${ }^{(\mathrm{S})}$ (30 June 1966); $\mathrm{H}_{2} \mathrm{O}(\mathrm{g})$, JANAF ${ }^{(6)}$ (31 March 1961).

- Calculation of $\Delta H_{\mathrm{r}}(298.15 \mathrm{~K})$ was based on the equation:

$$
\Delta H_{\mathrm{r}}(298.15 \mathrm{~K})=\Delta G_{\mathrm{r}}^{\circ}(T)-T \Delta\left\{G^{\circ}(T)-H^{\circ}(298.15 \mathrm{~K})\right\} / T .
$$

c The third-law drift, defined as the slope of a plot of $\Delta H_{\mathbf{r}}(298.15 \mathrm{~K})$ against $T$, is estimated as $(7 \pm 4) \mathrm{cal}_{\imath \mathrm{b}} \mathrm{K}^{-1} \mathrm{~mol}^{-1}$.

a Combination of this result with the subsidiary thermochemical data given in table 3 yields $-(301.2 \pm 0.6) \mathrm{kcal}_{\mathrm{kA}} \mathrm{mol}^{-1}$ for $\Delta H_{\mathrm{f}}^{\circ}$ of $\mathrm{ZnWO}_{4}$. 
TABLE 5. Analysis of solution-calorimetric data of Navrotsky and Kleppa ${ }^{(12)}$ \{solvent: $3 \mathrm{Na}_{2} \mathrm{O} \cdot 4 \mathrm{MoO}_{3}(\mathrm{l})$ \}

$\left(\mathrm{cal}_{\mathrm{ts}}=4.184 \mathrm{~J}\right)$

\begin{tabular}{lc}
\hline \multicolumn{1}{c}{ Reactions $^{a}$} & $\frac{\Delta H_{\mathrm{r}}^{\circ}(970 \mathrm{~K})}{\mathrm{kcal}_{\mathrm{th}} \mathrm{mol}^{-1}}$ \\
\hline $\mathrm{ZnO}(\mathrm{c})+$ solvent(l) $=$ solution I(l) & $-(3.20 \pm 0.06)^{b}$ \\
$\mathrm{WO}_{3}(\mathrm{c})+$ solvent(l) $=$ solution II(l) & $(7.24 \pm 0.18)^{\circ}$ \\
Solution III(l) $=\mathrm{ZnWO}(\mathrm{c})+2$ solvent(l) & $-(14.11 \pm 0.17)^{\circ}$ \\
Solution I(l) + solution II $(\mathrm{l})=$ solution III(l) & $(0.00)^{\mathrm{c}}$ \\
$\mathrm{ZnO}(\mathrm{c})+\mathrm{WO}_{3}(\mathrm{c})-\mathrm{ZnWO}_{4}(\mathrm{c})$ & $-(10.07 \pm 0.26)$
\end{tabular}

${ }^{a}$ Utilizing the thermal functions for $\mathrm{ZnWO}_{4}, \mathrm{ZnO}$, and $\mathrm{WO}_{3}$ from table $1, \mathrm{Kelley}^{(16)}$ and $J_{A N A F}^{(5)}$ (30 September 1966) respectively, results in a value of $-(9.90 \pm 0.3) \mathrm{kcal}_{\mathrm{tn}} \mathrm{mol}^{-1}$ for $\Delta H_{\mathrm{r}}^{\circ}\left(\mathrm{ZnWO}_{4}, \mathrm{c}\right)$ for formation from the oxides at $298.15 \mathrm{~K} . \Delta H_{f}^{\circ}\left(\mathrm{ZnWO}_{4}, \mathrm{c}\right)$ at $298.15 \mathrm{~K}$ is calculated as $-(294.6 \pm 0.3) \mathrm{kcal}_{\mathrm{th}} \mathrm{mol}^{-1}$, based on values at $298.15 \mathrm{~K}$ of -83.24 and $-201.45 \mathrm{kcal}_{\mathrm{tn}}$ $\mathrm{mol}^{-1}$ for $\Delta H_{\mathrm{r}}^{\circ}(\mathrm{ZnO}, \mathrm{c})$ and $\Delta H_{\mathrm{f}}^{\circ}\left(\mathrm{WO}_{3}, \mathrm{c}\right)$ of Wagman et al. ${ }^{(14,15)}$

- Navrotsky and Kleppa. ${ }^{(12)}$

${ }^{c}$ Undetermined, but assumed small because of the rather dilute solutions involved.

\section{Discussion}

From the summary given in table 6 , it is apparent that the second-law analysis of the data of Zharkova et al. ${ }^{(1)}$ is in exceedingly good accord with the result obtained from the data of Navrotsky and Kleppa, ${ }^{(12)}$ although the latter result is probably less subject to uncertainty. The third-law analysis of the equilibrium data, however, shows evidence for some thermodynamic inconsistency in this system. The relatively large third-law drift, $(7 \pm 4) \mathrm{cal}_{\mathrm{th}} \mathrm{K}^{-1} \mathrm{~mol}^{-1}$, is an indication that either the absolute values of $K_{p}$, or one or more of the values of $-\left\{G^{\circ}(T)-H^{\circ}(298.15 \mathrm{~K})\right\} / T$ are significantly in error. In view of the close agreement of the second-law analysis with the results of direct calorimetry, it is believed that systematic errors in $K_{p}$ values are the more likely source of the discrepancy in the third-law analysis.

TABLE 6. Summary of enthalpies of formation of zinc tungstate

$$
\left(\mathrm{cal}_{\mathrm{th}}=4.184 \mathrm{~J}\right)
$$

\begin{tabular}{|c|c|c|}
\hline$\frac{\Delta H_{\mathrm{f}}^{\circ}\left(\mathrm{ZnWO}_{4}, \mathrm{c}, 298.15 \mathrm{~K}\right)^{a}}{\mathrm{kcal}_{\mathrm{th}} \mathrm{mol}^{-1}}$ & $\frac{\Delta H_{\mathrm{r}}^{\mathrm{o}}\left(\mathrm{ZnWO}_{4}, \mathrm{c}, 298.15 \mathrm{~K}\right)^{b}}{\mathrm{kcal}_{\mathrm{th}} \mathrm{mol}^{-1}}$ & References \\
\hline $\begin{array}{l}-(294.6 \pm 0.3)^{c} \\
-(294.3 \pm 0.6)^{d} \\
-(301.2 \pm 0.6)^{e}\end{array}$ & $\begin{array}{r}-(9.9 \pm 0.3) \\
-(9.6 \pm 0.6) \\
-(16.5 \pm 0.6)\end{array}$ & $\begin{array}{l}\text { Navrotsky and Kleppa }{ }^{(13)} \\
\text { Zharkova et al. (11) Second Law } \\
\text { Zharkova et al. }{ }^{(11)} \text { Third Law }\end{array}$ \\
\hline
\end{tabular}

${ }^{a} \Delta H_{\mathrm{i}}$ from the elements.

b $\Delta H_{\mathrm{r}}^{\circ}$ for formation from the oxides $\left(\mathrm{ZnO}, \mathrm{WO}_{3}\right)$.

c See table 5 for details. Navrotsky and Kleppa ${ }^{(12)}$ reported only $\Delta H_{r}^{\circ}$ for formation from the oxides at $970 \mathrm{~K}$.

¿ See table 3 for details.

e See table 4 for details. The third-law drift is estimated as $(7 \pm 4) \mathrm{cal}_{\mathrm{th}} \mathrm{K}^{-1} \mathrm{~mol}^{-1}$. Urosov et al. $^{(1)}$ have given $S^{\circ}\left(\mathrm{ZnWO}_{4}, 298.15 \mathrm{~K}\right)$ as $(31.1 \pm 3) \mathrm{cal}_{\mathrm{th}} \mathrm{K}^{-1} \mathrm{~mol}^{-1}$ based on the equilibrium data. The discrepancy between this result and that determined calorimetrically, ${ }^{(3)}(28.34 \pm 0.1)$ $\mathrm{cal}_{\mathrm{th}} \mathrm{K}^{-1} \mathrm{~mol}^{-1}$, is consistent with the third-law drift. 
The value for $\Delta H_{\mathrm{f}}^{\circ}=-(294.6 \pm 0.3) \mathrm{kcal}_{\mathrm{th}} \mathrm{mol}^{-1}$ derived from the work of Navrotsky and Kleppa ${ }^{(12)}$ is selected here as the most reliable value for this quantity. This value may be compared with estimates and approximate calculations given by Wilcox and Bromley, ${ }^{(17)}-\left(293 \pm 15 \mathrm{kcal}_{\text {th }} \mathrm{mol}^{-1}\right.$, Urosov et al., ${ }^{(1)}-296 \mathrm{kcal}_{\mathrm{th}}$ $\mathrm{mol}^{-1}$, and Wagman et al., ${ }^{(15)}-293 \mathrm{kcal}_{\mathrm{th}} \mathrm{mol}^{-1}$. Using the selected value of $\Delta H_{\mathrm{f}}^{\circ}$ and the value ${ }^{(3)}$ of $S^{\circ}(298.15 \mathrm{~K})$ of $(28.34 \pm 0.1) \mathrm{cal}_{\mathrm{th}} \mathrm{K}^{-1} \mathrm{~mol}^{-1}$ results in a value of $\Delta G_{\mathrm{f}}^{\circ}\left(\mathrm{ZnWO}_{4}, \mathrm{c}, 298.15 \mathrm{~K}\right)=-(268.5 \pm 0.4) \mathrm{kcal}_{\mathrm{th}} \mathrm{mol}^{-1}$. The entropies of $\mathrm{Zn}(\mathrm{c}), \mathrm{W}(\mathrm{c})$, and $\mathrm{O}_{2}$ (g) were taken from the compilations of Wagman et al. ${ }^{(14,15)}$

\section{REFERENCES}

1. Urosov, V. S.; Ivanova, G. F.; Khodakovskii, I. L. Geokhimiya 1967, 10, 1050.

2. Lyon, W. G. Ph.D. Thesis, The University of Michigan, Ann Arbor, Michigan, Diss. Abstr. 1974 , in press.

3. Lyon, W. G.; Westrum, E. F., Jr. J. Chem. Thermodynamics 1974, 6, 763.

4. Zharkova, L. A.; Rezukhina, T. N. Zh. Fiz. Khim. 1958, 32, 2233.

5. JANAF Thermochemical Tables. The Dow Chemical Company.: Midland, Mich. (supplemental tables dated as indicated in text).

6. Dunning, N. J.; Megaw, H. D. Trans. Faraday Soc. 1946, 42, 705.

7. Shomate, C. H. J. Amer. Chem. Soc. 1944, 66, 928.

8. Schröcke, H. Beitr. Mineral. Petrogr. 1960, 7, 166.

9. O'Hara, S.; McManus, G. M. J. Appl. Phys. 1965, 36, 1741.

10. Yakovleva, R. A.; Rezukhina, T. N. Zh. Fiz. Khim. 1960, 34, 819. (Cf. Russ. J. Phys. Chem. $1960,34,390$.)

11. Zharkova, L. A.; Gerassimov, Ya. I.; Rezukhina, T. N.; Simanov, Yu. P. Dokl. Akad. Nauk SSSR 1959, 128 (5), 992. (Cf. Proc. Acad. Sci. USSR. 1959, 128 (5), 843.)

12. Navrotsky, A.; Kleppa, O. J. Inorg. Chem. 1969, 8, 756.

13. Hultgren, R.; Orr, R. L.; Anderson, P. D.; Kelley, K. K. Selected Values of Thermodynamic Properties of Metals and Alloys. Wiley: New York, 1963, Supplement (August, 1970).

14. Wagman, D. D.; Evans, W. H.; Parker, V. B.; Halow, I.; Bailey, S. M.; Schumm, R. H. Natl. Bur. Stand. (U.S.) Tech. Notes No. 270-3. U.S. Govt. Printing Office: Washington, D.C. 1968.

15. Wagman, D. D.; Evans, W. H.; Parker, V. B.; Halow, I.; Bailey, S. M.; Schumm, R. H. Natl. Bur. Stand. (U.S.) Tech. Notes No. 270-4. U.S. Govt. Printing Office: Washington, D.C. 1969.

16. Kelley, K.K. U.S. Bureau Mines Bull. No. 584. U.S. Govt. Printing Office: Washington, D.C. 1960.

17. Wilcox, D. E.; Bromley, L. A. Ind. Eng. Chem. 1963, 55(7), 32. 